\title{
Resistance of Botrytis cinerea Isolates from Vegetable Crops to Anilinopyrimidine, Phenylpyrrole, Hydroxyanilide, Benzimidazole, and Dicarboximide Fungicides
}

\author{
C. K. Myresiotis, Aristotelian University of Thessaloniki, Faculty of Agriculture, Plant Pathology Laboratory, POB \\ 269, 54124, Thessaloniki, Greece; G. S. Karaoglanidis, Hellenic Sugar Industry S.A., Plant Protection Department, \\ Sugar Factory of Platy, 59032, Platy Imathias, Greece; and K. Tzavella-Klonari, Aristotelian University of Thessa- \\ loniki, Faculty of Agriculture, Plant Pathology Laboratory, POB 269, 54124, Thessaloniki, Greece
}

\begin{abstract}
Myresiotis, C. K., Karaoglanidis, G. S., and Tzavella-Klonari, K. 2007. Resistance of Botrytis cinerea isolates from vegetable crops to anilinopyrimidine, phenylpyrrole, hydroxyanilide, benzimidazole, and dicarboximide fungicides. Plant Dis. 91:407-413.

During February 2005, 55 single-spore isolates of Botrytis cinerea were collected at the end of the season from vegetable crops grown in 18 greenhouses on the island of Crete, Greece. They were tested for sensitivity to the anilinopyrimidine fungicides pyrimethanil and cyprodinil, the hydroxyanilide fungicide fenhexamid, the phenylpyrrole fungicide fludioxonil, the dicarboximide fungicide iprodione, and the benzimidazole fungicide carbendazim. Results of the study showed the existence of benzimidazole- and dicarboximide-resistant strains at frequencies of 61.8 and $18 \%$, respectively. Moreover, for first time, the development of resistance to anilinopyrimidine fungicides by $B$. cinerea was detected in greenhouse vegetable crops on the island of Crete. High resistance frequencies of 49.1 and $57.4 \%$ were observed for pyrimethanil and cyprodinil, respectively. In addition, one isolate was found to be resistant to the hydroxyanilide fungicide fenhexamid, while no strains resistant to the phenylpyrrole fungicide were detected. Among the 55 isolates tested, 13 were resistant only to carbendazim, 6 were resistant only to anilinopyrimidines, 3 were resistant to both benzimidazoles and dicarboximides, 17 were resistant to both benzimidazoles and anilinopyrimidines, 6 were resistant to both dicarboximides and anilinopyrimidines, 1 was simultaneously resistant to benzimidazoles, dicarboximides, and anilinopyrimidines, 1 was resistant to both anilinopyrimidines and hydroxyanilides, and 8 were sensitive to all fungicides tested. A strong cross-resistance relationship was found between the two anilinopyrimidine fungicides tested when $\log$ transformed $\mathrm{EC}_{50}$ values of the isolates were subjected to a linear regression analysis $(r=0.71)$. Despite the detection of several phenotypes with simultaneous resistance to chemically unrelated active ingredients, in none of the remaining possible fungicide pairs was there observed any kind of cross-resistance relationship.
\end{abstract}

Gray mold, caused by Botrytis cinerea Pers.:Fr. (teleomorph Botryotinia fuckeliana), is among the most important diseases of greenhouse vegetable crops such as tomato, cucumber, pepper, and eggplant worldwide, causing significant yield losses. On Crete Island, a region of intensive vegetable production in Greece, the crops are grown in nonheated greenhouses and the disease is observed every year with very high intensity during the winter period (December to February).

Control of gray mold is based on an integration of several cultural methods with the use of fungicides belonging to several groups. Until the middle of the 1990s, chemical control of gray mold was mainly achieved by site-specific fungicides belonging to benzimidazoles, dicarboximides, and $N$-phenylcarbamate, while

Corresponding author: G. S. Karaoglanidis

E-mail: gkarao@agro.auth.gr

Accepted for publication 13 October 2006.

doi:10.1094/PDIS-91-4-0407

(C) 2007 The American Phytopathological Society multispecific inhibitors such as chlorothalonil, dichlofluanid, iminactodine, and captan were used only in tank mixtures or in rotation with site-specific inhibitors since their efficacy when used alone is relatively low (7). However, the intensive use of benzimidazole and dicarboximide fungicides has led to a rapid selection of resistant strains to one or both groups of fungicides both in Greece and in many other countries worldwide $(8,25,27)$. In the recent past, some new botryticides, belonging to newly developed groups of fungicides with different modes of action, were registered for use and introduced into the spray programs applied for the control of gray mold on vegetable crops worldwide. These new fungicides are the anilinopyrimidine derivatives pyrimethanil and cyprodinil, the hydroxyanilide derivative fenhexamid, and the phenylpyrrole derivative fludioxonil (32).

In the group of anilinopyrimidines belong three active ingredients, pyrimethanil, cyprodinil, and mepanipyrim. They have broad-spectrum activity including several important plant pathogens that belong to the Ascomycetes and to the Imperfect fungi. In Greece, they have been registered for use against gray mold caused by $B$. cinerea on vegetable crops since 1998. Cyprodinil has been registered for use against the disease in prepacked mixture with the phenylpyrrole fungicide fludioxonil. Anilinopyrimidine fungicides share a common mode of action consisting of inhibition of biosynthesis of methionine and other amino acids while they also inhibit the secretion of hydrolytic enzymes involved in the infection process of $B$. cinerea $(12,24)$. Strains of $B$. cinerea with high or weak resistance to anilinopyrimidines have already been detected on grapes $(11,13,21)$.

Fludioxonil is a phenylpyrrole fungicide registered in Greece for use against gray mold during 1998, in prepacked mixture with the anilinopyrimidine fungicide cyprodinil, as previously mentioned. Although the mechanism of action is not fully understood, it has been hypothesized that phenylpyrroles interfere with the osmotic signal transduction pathway, resulting in an abnormal accumulation of glycerol $(23,29)$. The biological activity of fludioxonil consists of inhibition of spore germination and hyphal growth (23). There has been no report of pathogen resistance in the field.

Fenhexamid is a hydroxyanilide derivative with high preventive activity against $B$. cinerea in various crops and other pathogens such as Monilinia spp. and Sclerotinia sclerotiorum. It has been available for use in Greece against gray mold in grapes and vegetable crops since 1999. It inhibits the germ tube elongation and mycelium growth at very low concentrations, by interfering with the $\mathrm{C}-4$ demethylation of sterol biosynthetic pathway $(5,23)$. Despite the fact that $B$. cinerea strains with reduced sensitivity to fenhexamid have been detected in a few cases, it did not lead to a total control failure in the field $(2,21)$. This absence of total control failures in the field could be explained by the lower fitness of the resistant strains (39) or the low degree of resistance.

Difficulties in obtaining high disease control efficacy by spray applications of several fungicides during the 2004-2005 winter period in greenhouse crops on Crete Island, compared with the satisfactory levels of control obtained during the previous years, enhanced the concerns of growers regarding the presence of fungicide- 
resistant strains of the pathogen in that region. Therefore, the current study was initiated to: (i) determine the levels of sensitivity of $B$. cinerea isolates obtained from several Crete Island greenhouses to anilinopyrimidine, phenylpyrrole, hydroxyanilide, dicarboximide, and benzimidazole fungicides, and (ii) investigate the cross-resistance patterns between the members of these fungicide groups using field isolates of the pathogen.

\section{MATERIALS AND METHODS}

Pathogen isolation. B. cinerea was isolated from diseased tomato, cucumber, and eggplant stems, leaves, flowers, or fruit. Diseased samples were collected from 18 greenhouses on Crete Island that had received three to seven fungicide spray applications against the disease. The complete fungicide spray schedule applied in each of the 18 greenhouses sampled, during the 2004-2005 growing period, is shown in Table 1 . The sampling was carried out during February 2005 after the last fungicide spray application at the end of the growing season. The samples were transferred to the laboratory in individual polyethylene bags to prevent crosscontamination and were incubated in sterile moist petri dishes at room temperature (22 to $23^{\circ} \mathrm{C}$ ) to obtain abundant conidia. When sporulation was obvious, from each sample, diseased pieces were transferred to
$100 \mathrm{ml}$ of distilled sterilized water and gently shaken to dislodge the conidia. From the resulting conidial suspension, single-spore isolates were obtained using the dilution technique (33). From each sample, only one isolate was obtained, and in total 55 isolates were collected. Nine of them were obtained from cucumber, 32 from tomato, and 14 from eggplant. The isolations were carried out on potato dextrose agar (PDA) (Oxoid, Basingstoke, UK) medium containing $0.5 \mathrm{ml} \mathrm{liter}^{-1} 1 \mathrm{~N}$ lactic acid to suppress bacteria. Singlespore isolates were maintained on PDA until use.

Media and sensitivity determination. Fungicides used in the study were the commercial formulations of cyprodinil (Chorus 50 WG, Syngenta Hellas, Athens, Greece), pyrimethanil (Scala 40 SC, BASF Hellas, Athens, Greece), fenhexamid (Teldor 50 WG, Bayer Hellas, Athens, Greece), fludioxonil (Medallion, $50 \mathrm{WP}$, Novartis Hellas, Athens, Greece), iprodione (Rovral 50 WP, BASF Hellas), and carbendazim (Pacarzim 50WP, Papaoikonomou Agrochemicals S.A., Thessaloniki, Greece). The fungicides were dissolved in sterilized distilled water, and stock solutions were prepared. Autoclaved PDA was cooled to $50^{\circ} \mathrm{C}$ and amended with aqueous fungicide solutions at the doses of $0.1,0.5,1,5$, and $10 \mu \mathrm{g} \mathrm{ml}^{-1}$ iprodione and $0.005,0.01,0.05$, and $0.1 \mu \mathrm{g}$ $\mathrm{ml}^{-1}$ fenhexamid by adding appropriate volumes of the fungicide stock solutions into the medium while it was still liquid. For the measurement of sensitivity to carbendazim, a single discriminatory concentration of $1 \mu \mathrm{g} \mathrm{ml}^{-1}$ was used, a concentration which is completely inhibitory for the benzimidazole-sensitive strains while allowing growth of resistant strains (9). For determining pathogen sensitivity to the anilinopyrimidine fungicides pyrimethanil and cyprodinil and the hydroxyanilide fungicide fludioxonil, a minimal medium instead of PDA was used containing $10 \mathrm{~g}$ glucose, $1.5 \mathrm{~g} \mathrm{~K}_{2} \mathrm{HPO}_{4}, 2 \mathrm{~g} \mathrm{KH}_{2} \mathrm{PO}_{4}, 1 \mathrm{~g}$ $\left(\mathrm{NH}_{4}\right)_{2} \mathrm{SO}_{4}, 0.5 \mathrm{~g} \mathrm{MgSO}_{4} \cdot 7 \mathrm{H}_{2} \mathrm{O}, 2 \mathrm{~g}$ yeast extract (Oxoid), and $12.5 \mathrm{~g}$ agar (Oxoid) per liter. Yeast extract was omitted in tests for the two anilinopyrimidine fungicides. Autoclaved medium was amended with $0.005,0.01,0.05,0.1,0.5$, and $1 \mu \mathrm{g} \mathrm{ml}^{-1}$ cyprodinil, $0.01,0.05,0.1,0.5,1$, and $5 \mu \mathrm{g}$ $\mathrm{ml}^{-1}$ pyrimethanil, and $0.001,0.005,0.01$, 0.05 , and $0.1 \mu \mathrm{g} \mathrm{ml}^{-1}$ fludioxonil. For isolates that were less sensitive to anilinopyrimidine fungicides, three additional concentrations of 5,10 , and $50 \mu \mathrm{g} \mathrm{ml}^{-1}$ cyprodinil and of 10,50 , and $100 \mu \mathrm{g} \mathrm{ml}^{-1}$ pyrimethanil were prepared. Control medium was not amended with fungicides. Tests for each isolate were replicated three times per concentration of each fungicide.

Mycelial plugs were removed, with the aid of a 5-mm-diameter cork borer, from

Table 1. Fungicide spray schedules applied to vegetable crops in the 18 sampled greenhouses on Crete Island for controlling gray mold caused by Botrytis cinerea during the 2004-2005 growing period

\begin{tabular}{|c|c|c|c|c|c|c|c|}
\hline \multirow[b]{2}{*}{ Greenhouse } & \multicolumn{7}{|c|}{ Fungicide spray application } \\
\hline & 1st & 2nd & 3rd & 4th & 5 th & 6th & 7th \\
\hline 1 & Copper hydroxide & Copper hydroxide & $\begin{array}{l}\text { Kasugamycin+ } \\
\text { chlorothalonil }\end{array}$ & Procymidone & Iprodione & $\cdots$ & $\cdots$ \\
\hline 2 & Copper hydroxide & Copper hydroxide & Iprodione & Vinclozoline & $\begin{array}{l}\text { Fludioxonil+ } \\
\text { cyprodinil }\end{array}$ & $\cdots$ & $\ldots$ \\
\hline 3 & $\begin{array}{l}\text { Kasugamycin+ } \\
\text { chlorothalonil }\end{array}$ & $\begin{array}{l}\text { Kasugamycin+ } \\
\text { chlorothalonil }\end{array}$ & Dichlofluanid & Iminoctadine & $\begin{array}{l}\text { Diethofencarb+ } \\
\text { carbendazim }\end{array}$ & $\cdots$ & $\cdots$ \\
\hline 4 & $\begin{array}{l}\text { Kasugamycin+ } \\
\text { chlorothalonil }\end{array}$ & Copper hydroxide & $\begin{array}{l}\text { Diethofencarb+ } \\
\text { carbendazim }\end{array}$ & Procymidone & $\begin{array}{l}\text { Diethofencarb+ } \\
\text { carbendazim }\end{array}$ & $\ldots$ & $\cdots$ \\
\hline 5 & Copper hydroxide & Copper hydroxide & Dichlofluanid & $\begin{array}{l}\text { Thiophanate } \\
\text { methyl }\end{array}$ & Fenhexamid & Iminoctadine & $\ldots$ \\
\hline 6 & Copper hydroxide & Copper hydroxide & Copper hydroxide & $\begin{array}{l}\text { Copper } \\
\text { hydroxide }\end{array}$ & Dichlofluanid & $\begin{array}{l}\text { Fludioxonil+ } \\
\text { cyprodinil }\end{array}$ & $\ldots$ \\
\hline 7 & $\begin{array}{l}\text { Kasugamycin+ } \\
\text { chlorothalonil }\end{array}$ & Copper hydroxide & $\begin{array}{l}\text { Diethofencarb+ } \\
\text { carbendazim }\end{array}$ & $\begin{array}{l}\text { Fludioxonil+ } \\
\text { cyprodinil }\end{array}$ & Dichlofluanid & Fenhexamid & $\cdots$ \\
\hline 8 & $\begin{array}{l}\text { Kasugamycin+ } \\
\text { chlorothalonil }\end{array}$ & $\begin{array}{l}\text { Kasugamycin+ } \\
\text { fenhexamid }\end{array}$ & Copper hydroxide & $\begin{array}{l}\text { Diethofencarb+ } \\
\text { carbendazim }\end{array}$ & Iminoctadine & $\cdots$ & $\ldots$ \\
\hline 9 & Copper hydroxide & Iminoctadine & $\begin{array}{l}\text { Diethofencarb+ } \\
\text { carbendazim }\end{array}$ & $\begin{array}{l}\text { Fludioxonil+ } \\
\text { cyprodinil }\end{array}$ & $\begin{array}{l}\text { Diethofencarb+ } \\
\text { carbendazim }\end{array}$ & Fenhexamid & $\ldots$ \\
\hline 10 & $\begin{array}{l}\text { Kasugamycin+ } \\
\text { chlorothalonil }\end{array}$ & $\begin{array}{l}\text { Kasugamycin+ } \\
\text { fenhexamid }\end{array}$ & $\begin{array}{l}\text { Diethofencarb+ } \\
\text { carbendazim }\end{array}$ & $\begin{array}{l}\text { Diethofencarb+ } \\
\text { carbendazim }\end{array}$ & $\begin{array}{l}\text { Fludioxonil+ } \\
\text { cyprodinil }\end{array}$ & Fenhexamid & $\begin{array}{l}\text { Dichlofluanid+ } \\
\text { pyrimethanil }\end{array}$ \\
\hline 11 & Copper hydroxide & Iminoctadine & $\begin{array}{l}\text { Diethofencarb+ } \\
\text { carbendazim }\end{array}$ & $\begin{array}{l}\text { Kasugamycin+ } \\
\text { fenhexamid }\end{array}$ & $\begin{array}{l}\text { Diethofencarb+ } \\
\text { carbendazim }\end{array}$ & $\cdots$ & $\ldots$ \\
\hline 12 & $\begin{array}{l}\text { Kasugamycin+ } \\
\text { chlorothalonil }\end{array}$ & Copper hydroxide & $\begin{array}{l}\text { Fludioxonil+ } \\
\text { cyprodinil }\end{array}$ & $\begin{array}{l}\text { Diethofencarb+ } \\
\text { carbendazim }\end{array}$ & Pyrimethanil & Fenhexamid & $\ldots$ \\
\hline 13 & $\begin{array}{l}\text { Kasugamycin+ } \\
\text { chlorothalonil }\end{array}$ & Copper hydroxide & Copper hydroxide & Fenhexamid & Iminoctadine & $\ldots$ & $\ldots$ \\
\hline 14 & Untreated greenhouse & & & & & & \\
\hline 15 & Copper hydroxide & $\begin{array}{l}\text { Fludioxonil+ } \\
\text { cyprodinil }\end{array}$ & Iprodione & $\begin{array}{l}\text { Fludioxonil+ } \\
\text { cyprodinil }\end{array}$ & $\begin{array}{l}\text { Diethofencarb+ } \\
\text { carbendazim }\end{array}$ & $\cdots$ & $\cdots$ \\
\hline 16 & Copper hydroxide & Copper hydroxide & Iminoctadine & $\ldots$ & $\ldots$ & $\ldots$ & $\ldots$ \\
\hline 17 & $\begin{array}{l}\text { Kasugamycin+ } \\
\text { chlorothalonil }\end{array}$ & $\begin{array}{l}\text { Kasugamycin+ } \\
\text { chlorothalonil }\end{array}$ & Iminoctadine & $\begin{array}{l}\text { Diethofencarb+ } \\
\text { carbendazim }\end{array}$ & $\cdots$ & $\cdots$ & $\cdots$ \\
\hline 18 & Copper hydroxide & Iminoctadine & Copper hydroxide & Iprodione & Fenhexamid & $\ldots$ & $\ldots$ \\
\hline
\end{tabular}


the colony margins of actively growing 72h-old colonies on PDA and placed upside down on the centers of $9-\mathrm{cm}$ plastic petri dishes containing the fungicide-amended or -unamended media. Cultures were incubated at $20^{\circ} \mathrm{C}$ in the dark for 3 days. Then, the mean colony diameter was measured and expressed as percentage of the mean diameter of the untreated control.

Data analysis. The $\mathrm{EC}_{50}$ value (effective concentration that reduces the mycelial growth by $50 \%$ ) of each isolate was calculated by regressing the relative inhibition of growth against the $\log _{10}$ fungicide concentration using SAS (JMP, SAS Institute, Cary, NC). Resistance frequencies were calculated based on discriminatory $\mathrm{EC}_{50}$ values of $1 \mu \mathrm{g} \mathrm{ml}^{-1}$ carbendazim, $1 \mu \mathrm{g} \mathrm{ml}^{-1}$ iprodione, $0.03 \mu \mathrm{g} \mathrm{ml}^{-1}$ cyprodinil, $0.1 \mu \mathrm{g}$ $\mathrm{ml}^{-1}$ pyrimethanil, $0.1 \mu \mathrm{g} \mathrm{ml}^{-1}$ fludioxonil, and $0.1 \mu \mathrm{g} \mathrm{ml}^{-1}$ fenhexamid, as determined in previous studies $(2,9,13,14,36)$. Isolates with $\mathrm{EC}_{50}$ values higher than the discriminatory concentrations, mentioned above, were considered to be resistant. To measure cross-resistance between pairs of the fungicides tested, correlation coefficients $(r)$ were calculated using SAS. The $\mathrm{EC}_{50}$ values were transformed to $\log _{10}$ values before analysis.

\section{RESULTS}

Sensitivity to dicarboximides. The 55 $B$. cinerea isolates tested showed a bimodal distribution of $\mathrm{EC}_{50}$ values to iprodione (Fig. 1A). The isolates were arbitrarily classified in categories with $\mathrm{EC}_{50}$ values $<0.2,0.2$ to $0.29,0.3$ to 0.39 ,
0.4 to $0.49,0.5$ to $0.59,0.6$ to $0.69,0.7$ to $0.79,0.8$ to $0.89,0.9$ to 0.99 , and $>1.0 \mu \mathrm{g}$ $\mathrm{ml}^{-1}$ iprodione. The $\mathrm{EC}_{50}$ values of the isolates ranged from 0.1 to $1.42 \mu \mathrm{g} \mathrm{ml}^{-1}$ iprodione (Table 2). Among the 55 isolates tested, 10 had an $\mathrm{EC}_{50}$ value higher than $1.0 \mu \mathrm{g} \mathrm{ml}^{-1}$ iprodione and were considered to be dicarboximide resistant (Table 3). The most resistant strain was separated from the most sensitive isolate by a resistance factor (RF) of 14.2. Among the 10 dicarboximide moderately resistant iso-

Table 2. Sensitivity of Botrytis cinerea isolates obtained from vegetable crops to pyrimethanil, cyprodinil, iprodione, fludioxonil, and fenhexamid

\begin{tabular}{lccc}
\hline Fungicide & No. of isolates & $\begin{array}{c}\mathbf{E C}_{\mathbf{5 0}} \text { values }\left(\boldsymbol{\mu g} \mathbf{~ m l}^{\mathbf{- 1}}\right) \\
\text { range }\end{array}$ & $\begin{array}{c}\text { Resistance frequency } \\
(\boldsymbol{\%})^{\mathbf{z}}\end{array}$ \\
\hline Pyrimethanil & 55 & $0.03-75$ & 49.1 \\
Cyprodinil & 54 & $0.003-25.2$ & 57.4 \\
Iprodione & 55 & $0.1-1.42$ & 18.1 \\
Fludioxonil & 54 & $0.001-0.008$ & 0.0 \\
Fenhexamid & 54 & $0.009-0.01$ & 1.8 \\
\hline
\end{tabular}

${ }^{\mathrm{z}}$ Resistance frequency values were determined based on $\mathrm{EC}_{50}$ discriminatory concentrations of $0.1 \mu \mathrm{g}$ $\mathrm{ml}^{-1}$ for pyrimethanil, $0.03 \mu \mathrm{g} \mathrm{ml}^{-1}$ for cyprodinil, $1 \mu \mathrm{g} \mathrm{ml}^{-1}$ for iprodione, $0.1 \mu \mathrm{g} \mathrm{ml} l^{-1}$ for fludioxonil, and $0.1 \mu \mathrm{g} \mathrm{ml}^{-1}$ for fenhexamid.
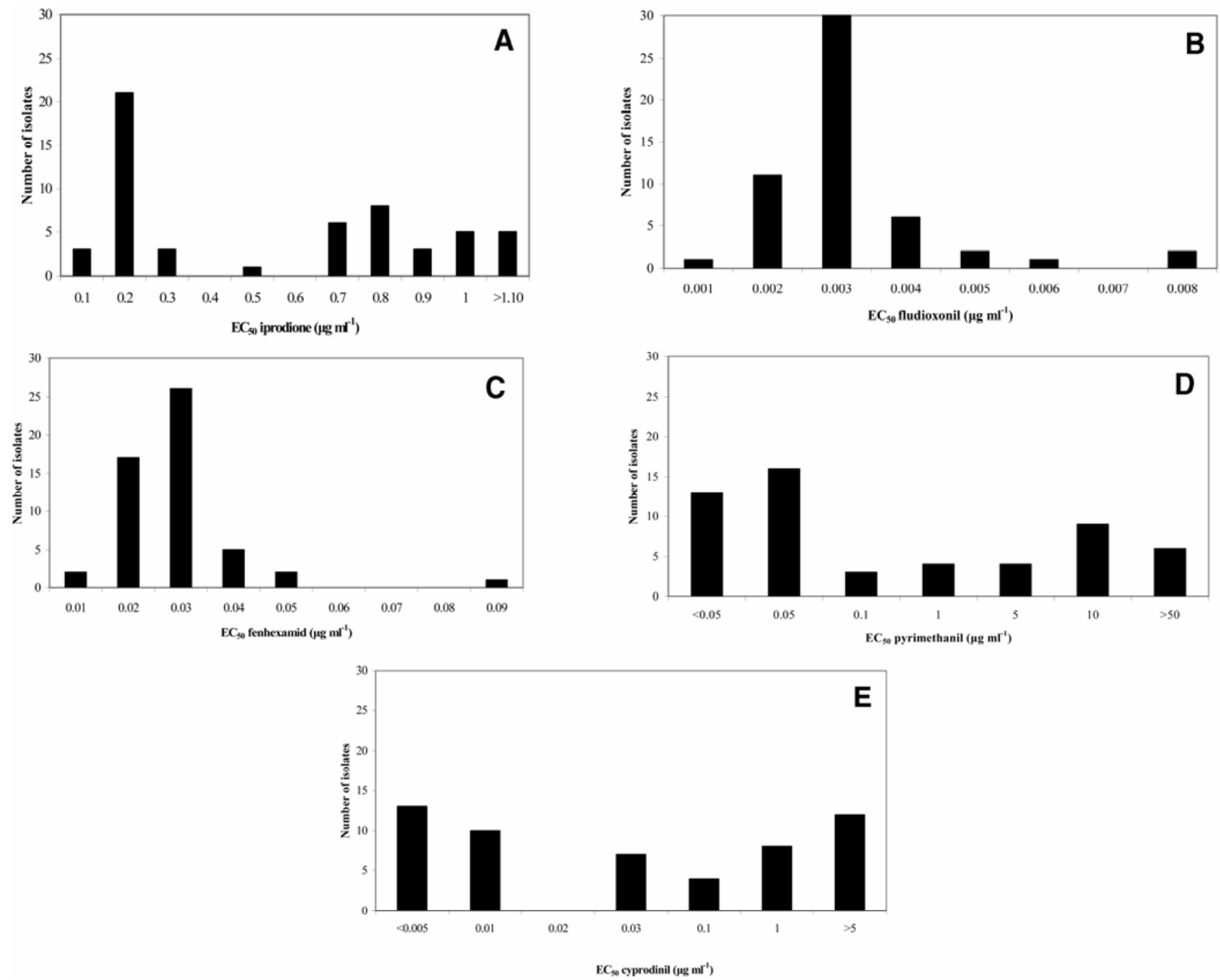

Fig. 1. Frequency distribution of $\mathrm{EC}_{50}$ values for $\mathbf{A}$, iprodione, $\mathbf{B}$, fludioxonil, $\mathbf{C}$, fenhexamid, $\mathbf{D}$, pyrimethanil, and $\mathbf{E}$, cyprodinil determined for single-spore isolates of Botrytis cinerea obtained from vegetable crops grown in greenhouses on Crete Island, Greece, after the end of the growing season in February 2005. 
lates, 3 were also resistant to the benzimidazole fungicide carbendazim, 6 were also resistant to the anilinopyrimidine fungicide cyprodinil, and 1 was simultaneously resistant to iprodione, carbendazim, and cyprodinil. None of the isolates was resistant only to dicarboximides (Table 3 ).

Sensitivity to benzimidazoles. Sensitivity of the isolates to the benzimidazole fungicide carbendazim was determined based on the discriminatory concentration of $1 \mu \mathrm{g}$ $\mathrm{ml}^{-1}$ carbendazim, a concentration completely inhibitory for the sensitive strains while allowing growth of resistant strains. Among the 55 isolates tested, 34 were found to be resistant to carbendazim. Among these 34 resistant isolates, 3 were also resistant to dicarboximides, 17 were also resistant to anilinopyrimidines, 1 was simultaneously resistant to carbendazim, iprodione, and cyprodinil, and 13 isolates were resistant only to benzimidazoles (Table 3).
Sensitivity to anilinopyrimidines. The anilinopyrimidine fungicides selected for the study were cyprodinil and pyrimethanil. $\mathrm{EC}_{50}$ value distributions for both cyprodinil and pyrimethanil showed an abnormal pattern suggesting monogenic control of resistance (Fig. 1D and E, for pyrimethanil and cyprodinil, respectively). The isolates were arbitrarily classified in categories with $\mathrm{EC}_{50}$ values $<0.05,0.05$ to $0.1,0.1$ to 1,1 to 5,5 to 10,10 to 50 , and

Table 3. Phenotypic characterization of Botrytis cinerea isolates based on discriminatory concentrations ${ }^{\mathrm{w}}$ of several fungicides

\begin{tabular}{|c|c|c|c|c|c|c|}
\hline \multirow[b]{2}{*}{ Isolate } & \multirow[b]{2}{*}{ Host } & \multicolumn{5}{|c|}{ Fungicide } \\
\hline & & Carbendazim & Iprodione & Cyprodinil & Fludioxonil & Fenhexamid \\
\hline $1 a^{x}$ & Eggplant & $t^{\mathrm{y}}$ & - & - & - & - \\
\hline $1 \mathrm{c}$ & Eggplant & - & - & - & - & - \\
\hline $1 d$ & Eggplant & - & - & + & - & - \\
\hline $2 \mathrm{a}$ & Eggplant & - & - & - & - & - \\
\hline $2 b$ & Eggplant & + & - & - & - & - \\
\hline $3 a$ & Tomato & + & - & - & - & - \\
\hline $3 b$ & Tomato & + & - & - & - & - \\
\hline $4 a$ & Tomato & - & - & + & - & - \\
\hline $5 a$ & Tomato & - & - & + & - & - \\
\hline $6 a$ & Tomato & + & - & - & - & - \\
\hline $6 b$ & Tomato & + & - & - & - & - \\
\hline $7 \mathrm{a}$ & Eggplant & - & - & + & $\mathrm{nd}^{\mathrm{z}}$ & - \\
\hline $7 b$ & Eggplant & + & + & - & - & - \\
\hline $7 \mathrm{c}$ & Eggplant & + & - & + & - & - \\
\hline $7 \mathrm{~d}$ & Eggplant & + & + & - & - & - \\
\hline $7 \mathrm{e}$ & Eggplant & - & - & + & - & - \\
\hline $8 \mathrm{a}$ & Tomato & + & - & + & - & - \\
\hline $8 \mathrm{~b}$ & Tomato & + & + & + & - & - \\
\hline $8 c$ & Tomato & + & - & + & - & - \\
\hline $8 \mathrm{~d}$ & Tomato & + & - & - & - & - \\
\hline $8 \mathrm{e}$ & Tomato & - & - & - & - & - \\
\hline $9 b$ & Tomato & + & - & nd & - & nd \\
\hline $9 \mathrm{c}$ & Tomato & + & - & + & - & - \\
\hline $9 \mathrm{~d}$ & Tomato & + & - & + & - & - \\
\hline $9 \mathrm{e}$ & Tomato & - & - & - & - & - \\
\hline $10 \mathrm{a}$ & Cucumber & + & - & + & - & - \\
\hline $10 \mathrm{~b}$ & Cucumber & + & - & + & - & - \\
\hline $10 \mathrm{c}$ & Cucumber & + & - & + & - & - \\
\hline $10 \mathrm{~d}$ & Cucumber & + & - & + & - & - \\
\hline $10 \mathrm{e}$ & Cucumber & + & - & + & - & - \\
\hline $11 \mathrm{~b}$ & Cucumber & - & - & + & - & + \\
\hline $11 \mathrm{~d}$ & Cucumber & + & - & + & - & - \\
\hline $12 \mathrm{a}$ & Cucumber & + & - & + & - & - \\
\hline $12 \mathrm{e}$ & Cucumber & + & - & + & - & - \\
\hline $13 b$ & Tomato & - & + & + & - & - \\
\hline $13 \mathrm{c}$ & Tomato & + & - & - & - & - \\
\hline $13 \mathrm{~d}$ & Tomato & + & - & + & - & - \\
\hline $13 \mathrm{e}$ & Tomato & - & - & - & - & - \\
\hline $14 \mathrm{a}$ & Eggplant & - & - & - & - & - \\
\hline $14 \mathrm{~d}$ & Eggplant & - & - & - & - & - \\
\hline $15 \mathrm{a}$ & Tomato & + & - & + & - & - \\
\hline $15 \mathrm{c}$ & Tomato & + & + & - & - & - \\
\hline $15 \mathrm{~d}$ & Tomato & + & - & - & - & - \\
\hline $16 a$ & Tomato & + & - & - & - & - \\
\hline $16 \mathrm{~b}$ & Tomato & + & - & - & - & - \\
\hline $16 \mathrm{c}$ & Tomato & - & - & + & - & - \\
\hline $16 \mathrm{~d}$ & Tomato & - & + & + & - & - \\
\hline $16 \mathrm{e}$ & Tomato & - & - & - & - & - \\
\hline $17 \mathrm{a}$ & Tomato & + & - & + & - & - \\
\hline $17 \mathrm{~b}$ & Tomato & + & - & - & - & - \\
\hline $17 \mathrm{c}$ & Tomato & + & - & + & - & - \\
\hline $17 \mathrm{~d}$ & Tomato & - & + & + & - & - \\
\hline $18 \mathrm{a}$ & Tomato & - & + & + & - & - \\
\hline $18 \mathrm{~b}$ & Tomato & - & + & + & - & - \\
\hline $18 \mathrm{c}$ & Tomato & - & + & + & - & - \\
\hline
\end{tabular}

${ }^{\text {w}}$ The discriminatory concentrations used were $1 \mu \mathrm{g} \mathrm{ml} l^{-1}$ carbendazim, $1 \mu \mathrm{g} \mathrm{ml}^{-1}$ iprodione, $0.03 \mu \mathrm{g} \mathrm{ml}^{-1}$ cyprodinil, $0.1 \mu \mathrm{g} \mathrm{ml}{ }^{-1}$ fludioxonil, and $0.1 \mu \mathrm{g} \mathrm{ml}{ }^{-1}$ fenhexamid.

${ }^{x}$ Numbers in the isolates' names refer to the greenhouse sampled.

y " + " indicates resistant isolate and "-" indicates sensitive isolate.

${ }^{\mathrm{z}}$ nd: not determined. 
$>50 \mu \mathrm{g} \mathrm{ml}^{-1}$ to pyrimethanil, and $<0.005$, 0.005 to $0.02,0.02$ to $0.03,0.03$ to $0.1,0.1$ to 1,1 to 5 , and $>5 \mu \mathrm{g} \mathrm{ml}^{-1}$ to cyprodinil. The $\mathrm{EC}_{50}$ values of the isolates ranged from 0.003 to $25.2 \mu \mathrm{g} \mathrm{ml}^{-1}$ and from 0.03 to $75.0 \mu \mathrm{g} \mathrm{ml} \mathrm{m}^{-1}$ for cyprodinil and pyrimethanil, respectively (Table 2 ). The most resistant strain was separated from the most sensitive isolate by an RF value of 8,400 for cyprodinil, while for pyrimethanil the most resistant strain was separated from the most sensitive isolate by an RF value of 2,500. Among the isolates tested, 31 had an $\mathrm{EC}_{50}$ value higher than $0.03 \mu \mathrm{g} \mathrm{ml}^{-1}$ cyprodinil and were considered to be anilinopyrimidine resistant (Table 3). Among these 31 isolates, 17 were also resistant to the benzimidazole fungicide carbendazim, 6 were also resistant to the dicarboximide fungicide iprodione, 1 isolate was also resistant to fenhexamid, 1 isolate was simultaneously resistant to cyprodinil, carbendazim, and iprodione, and 6 isolates were resistant only to cyprodinil (Table 3 ).

Sensitivity to phenylpyrroles. The phenylpyrrole fungicide selected for the study was fludioxonil. The $54 \mathrm{~B}$. cinerea isolates tested showed a normal distribution of $\mathrm{EC}_{50}$ values to fludioxonil (Fig. 1B). The isolates were arbitrarily classified in categories with $\mathrm{EC}_{50}$ values $<0.002$, 0.002 to $0.0029,0.003$ to $0.0039,0.004$ to $0.0049,0.005$ to 0.0059 , and $>0.006 \mu \mathrm{g} \mathrm{ml}^{-1}$ fludioxonil. The $\mathrm{EC}_{50}$ values of the isolates ranged from 0.001 to $0.008 \mu \mathrm{g} \mathrm{ml}^{-1}$ fludioxonil (Table 2). Although the most resistant strain was separated from the most sensitive isolate by an RF of 8 , none of the isolates is considered to be resistant based on the discriminatory concentration of 0.1 $\mu \mathrm{g} \mathrm{ml}^{-1}$ fludioxonil (Table 3 ).

Sensitivity to hydroxyanilides. The hydroxyanilide fungicide selected for the study was fenhexamid. The $53 \mathrm{~B}$. cinerea isolates tested showed a normal distribution of $\mathrm{EC}_{50}$ values to fenhexamid (Fig. 1C). The isolates were arbitrarily classified in categories with $\mathrm{EC}_{50}$ values $<0.02,0.02$ to $0.029,0.03$ to $0.039,0.04$ to $0.049,0.05$ to 0.059 , and $>0.06 \mu \mathrm{g} \mathrm{ml}^{-1}$ fenhexamid. The $\mathrm{EC}_{50}$ values of the isolates ranged from 0.009 to $0.01 \mu \mathrm{g} \mathrm{ml}{ }^{-1}$ fenhexamid (Table 2). Among the isolates tested, there was one with $\mathrm{EC}_{50}$ value of $0.1 \mu \mathrm{g} \mathrm{ml}^{-1}$ fenhexamid, which is the discriminatory limit for resistance to fenhexamid. This isolate was sensitive to benzimidazole, dicarboximide, and phenylpyrroles fungicides but moderately resistant to the anilinopyrimidine fungicide cyprodinil (Table 3).

Cross-resistance patterns. Sensitivity to each fungicide was plotted versus sensitivity to the other fungicides, and the logtransformed $\mathrm{EC}_{50}$ values were analyzed by establishing correlations and linear regressions. Data on the correlation coefficients between all the fungicide pairs are summarized in Table 4. The correlation coefficient ( $r$ ) of sensitivity between the two anilinopyrimidine fungicides pyrimethanil and cyprodinil had a value of $0.71(P<0.05)$, indicating a positive cross-resistance pattern between these two fungicides. In all the other combinations tested, correlation coefficients were very low and none of them was significant $(P>0.05)$.

\section{DISCUSSION}

B. cinerea represents a classic "high risk" pathogen for resistance development due to its high genetic variability and flexibility, its abundant sporulation, the polycyclic nature of the disease it causes, its wide host range, and the high number of fungicide applications required for its successful control. Indeed, during the past, some of the most serious problems of fungicide resistance development occurred with this pathogen (3). Moreover, almost all the newly introduced botryticides, including anilinopyrimidines, phenylpyrroles, and hydroxyanilides, face the possibility of resistance development, as has already been shown by several studies carried out with laboratory mutants of the pathogen $(4,10,39)$. In this study, we determined the sensitivity of $55 \mathrm{~B}$. cinerea single-spore isolates obtained from tomato, cucumber, and eggplant grown in greenhouses on Crete Island to several fungicides used currently to control gray mold.

Results of this study confirm findings of previous studies reporting wide occurrence of dicarboximide- and benzimidazoleresistant isolates of $B$. cinerea obtained from vegetable crops grown in greenhouses on the island of Crete $(26,27)$. All the dicarboximide-resistant isolates showed only low resistance to iprodione $\left(\mathrm{EC}_{50}\right.$ for mycelium growth from 1 to 1.5 $\left.\mu \mathrm{g} \mathrm{ml}^{-1}\right)$; none of them was highly resistant. This level of resistance has been asso- ciated with the ability to cause disease in plants treated with label rates of dicarboximide fungicides (19). These results are consistent with the findings of previous reports suggesting that highly resistant strains are only rarely isolated from the field and most of the resistant strains show only low resistance levels $(25,36,37)$. Moreover, none of the 10 dicarboximideresistant isolates was only resistant to iprodione. Six iprodione-resistant isolates were also resistant to cyprodinil, three were also resistant to carbendazim, and one was simultaneously resistant to iprodione, carbendazim, and cyprodinil. However, the observed resistance frequency of $18.1 \%$ in the current study is lower than that reported by Pappas (27), who monitored the fungal population in the same region after the end of the 1993, 1994, and 1995 growing seasons and found that the dicarboximide resistance frequency ranged from 30 to $36 \%$. Obviously, the implementation of antiresistance strategies consisting of a maximum of one spray application of dicarboximide fungicides, per growing season accounts for this reduction of resistance frequency and is associated with the decreased fitness and the decreased survival ability of dicarboximide-resistant strains of the pathogen in the absence of selection pressure $(25,31)$. Moreover, shifts toward increased sensitivity to dicarboximides have been frequently observed during the "dormant" oversummering or overwintering saprophytic phase when no fungicides were applied $(16,17,27)$. In contrast, resistance frequency to benzimidazoles remained high despite the fact that they were only rarely used after the emergence of resistance to this fungicide class. This long persistence of high benzimidazole resistance frequency, even in the absence of selection pressure, could be related to the high fitness of the benzimidazole-resistant strains (30,37).

Anilinopyrimidine fungicides have been used in Greece against gray mold of vegetable crops since the 1998-1999 winter period. In some cases, more than two spray applications of these fungicides per growing season were carried out. The results of the study showed that after 7 years of use, a strongly resistant pathogen subpopulation has developed reaching frequencies of 57 and $49 \%$ for cyprodinil and pyrimetha-

Table 4. Patterns of cross-resistance between pyrimethanil, cyprodinil, fludioxonil, fenhexamid, and iprodione in Botrytis cinerea isolates obtained from vegetable crops

\begin{tabular}{|c|c|c|c|c|c|c|c|c|}
\hline \multirow[b]{3}{*}{ Fungicide } & \multicolumn{8}{|c|}{ Fungicide } \\
\hline & \multicolumn{2}{|c|}{ Cyprodinil } & \multicolumn{2}{|c|}{ Fludioxonil } & \multicolumn{2}{|c|}{ Fenhexamid } & \multicolumn{2}{|c|}{ Iprodione } \\
\hline & $r$ & $P^{z}$ & $r$ & $\boldsymbol{P}$ & $r$ & $P$ & $r$ & $P$ \\
\hline Pyrimethanil & 0.71 & 0.0001 & 0.04 & 0.98 & 0.02 & 0.85 & 0.2 & 0.11 \\
\hline Cyprodinil & - & - & 0.04 & 0.72 & 0.10 & 0.46 & 0.2 & 0.14 \\
\hline Fludioxonil & - & - & - & - & 0.17 & 0.16 & 0.08 & 0.52 \\
\hline Fenhexamid & - & - & - & - & - & - & 0.14 & 0.30 \\
\hline
\end{tabular}

${ }^{\mathrm{z}}$ Correlation coefficients are significant at $P<0.05$. 
nil, respectively. Although there are no available baseline data from the sampling region allowing direct comparisons, monitoring programs carried out in France and Switzerland before the introduction of anilinopyrimidines into commercial practice had showed that resistance frequencies to anilinopyrimidines were very low $(<1 \%)$ $(11,13)$. Moreover, the RF of some of the isolates were extremely high, reaching values of several thousand. To the best of our knowledge, this is the first report of resistance buildup to anilinopyrimidine fungicides in $B$. cinerea populations obtained from vegetable crops. The abnormal pyrimethanil and cyprodinil sensitivity distribution of the pathogen population observed in the current study suggests that a qualitative, disruptive selection for resistance has occurred which is typical for one-gene mutation. Indeed, several previous studies reported that resistance to anilinopyrimidine fungicides is monogenically controlled $(1,4,13)$. The existence of a strong cross-resistance relationship between anilinopyrimidine fungicides is in agreement with the findings of previous reports $(11,14,20,21)$.

Among the 31 isolates found to be resistant to cyprodinil, only eight $(25.8 \%)$ were resistant to just this class of fungicides. In most of these isolates, resistance was very strong with RF values of several thousand. The remaining 23 anilinopyrimidineresistant isolates $(74.2 \%)$ exhibited resistance to other fungicides including carbendazim, iprodione, and fenhexamid. Most of these 23 isolates showed resistance factors lower than those of the isolates exhibiting resistance only to anilinopyrimidines. Despite the existence of phenotypes with simultaneous resistance to anilinopyrimidine, dicarboximide, benzimidazole, and hydroxyanilide fungicides, the results of our study showed that there is no correlation among the sensitivities to these fungicide classes, suggesting the absence of a positive cross-resistance relationship among them. The absence of positive crossresistance between anilinopyrimidine fungicides and benzimidazole, dicarboximide, or hydroxyanilide fungicides has also been reported in previous studies $(11,12,28,39)$. The phenomenon of simultaneous resistance observed in this study could be explained by the hypothesis put forth by Köller and Wilcox (18), which was that resistance development to one fungicide class accelerates resistance development to another unrelated fungicide class. The mechanism of this simultaneous resistance could be a decreased accumulation of the compounds in mycelium due to an energydependent efflux of the fungicides. This mechanism could be generated by the overexpression of ATP-binding cassette (ABC) transporters that may result in overproduction of encoded proteins and in increased pump capacity responsible for the energydependent efflux of fungicides $(6,22,34)$.
In the current study, no shift toward decreased sensitivity to fludioxonil was observed. However, the sample size was too small to detect a low frequency of phenotype with reduced sensitivity to fludioxonil. To the best of our knowledge, there has been no report of resistance development of $B$. cinerea to fludioxonil in the field, and this is probably due to the polygenic control of the resistance as has been shown recently by Vignutelli et al. (35) and Ziogas et al. (40). Moreover, the polygenic control of resistance to fludioxonil may be responsible for the reduced fitness of fludioxonil-resistant isolates of $B$. cinerea obtained in the laboratory $(15,38)$ or the reduced competitive ability of the fludioxonil-resistant strains compared with the wild-type strain (40). The development of fludioxonil resistance in the field might have detrimental effects on the survival of the pathogen. Despite the fact that in some previous studies laboratory-induced resistant isolates to fludioxonil were also resistant to dicarboximide fungicides $(15,35,40)$, in the present study no cross-resistance relationship between these two fungicide groups in field isolates of $B$. cinerea was observed. A similar conclusion was previously reported by Leroux et al. (21).

Similarly, no shift toward decreased sensitivity to fenhexamid, the most recently introduced botryticide, was observed in the current study. Almost all the isolates tested showed a very narrow sensitivity distribution, and only one isolate had an $\mathrm{EC}_{50}$ value of $0.1 \mu \mathrm{g} \mathrm{ml}^{-1}$, which is the concentration suggested for the discrimination between the fenhexamid-resistant and -sensitive strains of the pathogen (2). Early considerations related to the risk of resistance development to fenhexamid, before the commercial introduction of the fungicide, suggested a high risk (21) supported by the high mutation frequency of highly fenhexamid-resistant mutants reported by Ziogas et al. (39). In a recent study, populations of $B$. cinerea from grapes were fully resistant to fenhexamid, but this resistance development did not affect the field performance of the fungicide (2). The results of our study showed that there was no significant correlation between sensitivity to fenhexamid and sensitivity to anilinopyrimidine, phenylpyrrole, and dicarboximide fungicides. In contrast, in a previous study of $B$. cinerea strains with laboratory-induced resistance to fenhexamid, a negative cross-resistance between fenhexamid and phenylpyrroles and dicarboximides was observed, while there was no correlation between sensitivity to fenhexamid and anilinopyrimidines (39).

In almost all of the greenhouses sampled, disease control was based on applications of several fungicides in mixtures or in alternations as a strategy to delay resistance development or resistance evolution. However, fungicide resistance did not appear to be related to fungicide use in each particular greenhouse examined. This may be due to the movement of fungicideresistant $B$. cinerea strains between different greenhouses or between greenhouses and neighboring grape vineyards that are treated with the same fungicides to control the pathogen. Benzimidazole-resistant strains were not detected in only 4 out of 18 greenhouses sampled, despite the fact that in these four greenhouses carbendazim had been used during the 2004-2005 growing season, in one- or two-spray applications in mixture with diethofencarb. Perhaps a larger sample from each greenhouse would have enabled detection of benzimidazole-resistant phenotypes. Similarly, anilinopyrimidine-resistant strains were detected in 14 out of 18 greenhouses sampled. However, according to the fungicide spray programs supplied to us by the growers, anilinopyrimidine fungicides had been used during the 2004-2005 growing season only in seven greenhouses.

Monitoring data obtained in the current study demonstrated that $B$. cinerea populations from greenhouse vegetable crops on Crete Island did not shift toward decreased sensitivity to fludioxonil and to fenhexamid, but despite the implementation of antiresistance strategies, selection of resistant strains to anilinopyrimidine fungicides has occurred. The high resistance frequency and the high levels of resistance in some of the tested isolates likely accounts for the decreased efficacy of control observed during 2004-2005 in some of the greenhouses sampled, compared with the higher control efficacy obtained during previous years. Maintaining the high activity of fludioxonil and fenhexamid against $B$. cinerea by delaying resistance development and delaying the evolution of resistance to anilinopyrimidines by limiting the number of applications is a prerequisite for successful control of gray mold. These strategies should be accompanied by continuous monitoring for early detection of any change in pathogen sensitivity to these fungicides.

\section{ACKNOWLEDGMENTS}

We thank A. Avgelis for providing the diseased plant material used for pathogen isolations.

\section{LITERATURE CITED}

1. Babij, J., Zhu, Q., Brain, P., and Hollomon, D. W. 2000. Resistance risk assessment of cereal eyespot, Tapesia yallundae and Tapesia acuformis, to the anilinopyrimidine fungicide, cyprodinil. Eur. J. Plant Pathol. 106:895-905.

2. Baroffio, C. A., Siegfried, W., and Hilber, U. W. 2003. Long-term monitoring for resistance of Botryotinia fuckeliana to anilinopyrimidine, phenylpyrrole, and hydroxyanilide fungicides in Switzerland. Plant Dis. 87:662-666.

3. Brent, K. J. 1995. Fungicide resistance in crop pathogens: How can it be managed? FRAC Monogr. No. 1, GIFAP, Brussels.

4. Chapeland, F., Fritz, R., Lanen, C., Gredt, M. and Leroux, P. 1999. Inheritance and mechanisms of resistance to anilinopyrimidine fungicides in Botrytis cinerea (Botryotinia fuckeliana). Pestic. Biochem. Physiol. 64:85-100.

5. Debieu, D., Bach, J., Hugon, M., Malosse, C., 
and Leroux, P. 2001. The hydroxyanilide fenhexamid, a new sterol biosynthesis inhibitor fungicide efficient against the plant pathogenic fungus Botryotinia fuckeliana (Botrytis cinerea). Pest Manag. Sci. 57:1060-1067.

6. De Waard, M. A. 1997. Significance of ABC transporters in fungicide sensitivity and resistance. Pestic. Sci. 51:271-275.

7. Elad, Y., Gullino, M. L., Shtienberg, D., and Aloi, C. 1995. Managing Botrytis cinerea on tomatoes in greenhouses in the Mediterranean. Crop Prot. 14:105-109.

8. Elad, Y., Yunis, H., and Katan, T. 1992. Multiple resistance to benzimidazoles, dicarboximides and diethofencarb in field isolates of Botrytis cinerea in Israel. Plant Pathol. 41:41-46.

9. Faretra, F., and Pollastro, S. 1991. Genetic basis of resistance to benzimidazol and dicarboximide fungicides in Botryotinia fuckeliana (Botrytis cinerea). Mycol. Res. 95:943-951.

10. Faretra, F., and Pollastro, S. 1993. Isolation, characterization and genetic analysis of laboratory mutants of Botryotinia fuckeliana resistant to the phenylpyrrole fungicide CGA 173506. Mycol. Res. 97:620-624.

11. Forster, B., and Staub, T. 1996. Basis for use strategies of anilinopyrimidine and phenylpyrrole fungicides against Botrytis cinerea. Crop Prot. 15:529-537.

12. Heye, U. J., Speich, J., Siegle, H., Steinemann, A., Forster, B., Knauf-Beiter, G., Herzog, J., and Hubele, A. 1994. CGA 219417: A novel broad-spectrum fungicide. Crop Prot. 13:541549.

13. Hilber, U. W., and Hilber-Bodmer, M. 1998. Genetic basis and monitoring of resistance of Botryotinia fuckeliana to anilinopyrimidines. Plant Dis. 82:496-500.

14. Hilber, U. W., and Schüepp, H. 1996. A reliable method for testing the sensitivity of Botryotinia fuckeliana to anilinopyrimidines in vitro. Pestic. Sci. 47:241-247.

15. Hilber, U. W., Schüepp, H., and Schwinn, F. J. 1994. Resistance risk evaluation of fludioxonil, a new phenylpyrrole fungicide. Pages 397-402 in: Fungicide Resistance BCPC Monogr. No. 60. S. Heaney, D. Slawson, D. W. Hollomon, M. Smith, P. E. Russell, and D. W. Parry, eds. British Crop Protection Council, Surrey, England.

16. Hunter, T., Brent, K. J., Carter, G. A., and Hutcheon, J. A. 1987. Effects of fungicide spray regimes on incidence of dicarboximide resistance in grey mould (Botrytis cinerea) on strawberry plants. Ann. Appl. Biol. 110:515-525.

17. Katan, T. 1985. Effect of chlorothalonil on resistance of Botrytis cinerea to dicarboximides in cucumber glasshouses. EPPO Bull. 15:365-369.

18. Köller, W., and Wilcox, W. F. 2001. Evidence for the predisposition of fungicide-resistant isolates of Venturia inaequalis to a preferential selection for resistance to other fungicides. Phytopathology 91:776-781.

19. LaMondia, J. A., and Douglas, S. M. 1997. Sensitivity of Botrytis cinerea from Connecticut greenhouses to benzimidazole and dicarboximide fungicides. Plant Dis. 81:729-732.

20. Latorre, B. A., Spadaro, I., and Rioja, M. E. 2002. Occurrence of resistant strains of Botrytis cinerea to anilinopyrimidine fungicides in table grapes in Chile. Crop Prot. 21:957-961.

21. Leroux, P., Chapeland, F., Desbrosses, D., and Gredt, M. 1999. Patterns of cross-resistance to fungicides in Botryotinia fuckeliana (Botrytis cinerea) isolates from French vineyards. Crop Prot. 18:687-697.

22. Leroux, P., Chapeland, F., Giraud, T., Brygoo, Y., and Gredt, M. 1999. Resistance to sterol biosynthesis inhibitors and various other fungicides in Botrytis cinerea. Pages 297-303 in: Modern fungicides and antifungal compounds II. H. Lyr, P. E. Russell, H. W. Dehne, and H. D. Sisler, eds. Intercept Ltd., Andover, UK.

23. Leroux, P., Fritz, R., Debieu, D., Albertini, C., Lanen, C., Bach, J., Gredt, M., and Chapeland, F. 2002. Mechanisms of resistance to fungicides in field strains of Botrytis cinerea. Pest Manag. Sci. 58:876-888.

24. Masner, P., Muster, P., and Schmid, J. 1994. Methionine biosynthesis inhibition by pyrimidinamine fungicides in Botrytis cinerea. Pestic. Sci. 42:163-166.

25. Moorman, G. W., and Lease, R. J. 1992. Benzimidazole and dicarboximide-resistant Botrytis cinerea from Pennsylvania greenhouse. Plant Dis. 76:477-480.

26. Panagiotakou, M., and Malathrakis, N. F. 1983. Resistance of Botrytis cinerea to dicarboximide fungicides in protected crops. Ann. Appl. Biol. 102:293-299.

27. Pappas, A. C. 1997. Evolution of fungicide resistance in Botrytis cinerea in protected crops in Greece. Crop Prot. 16:257-263.

28. Petsikos-Panayotarou, N., Markellou, E., Kalamarakis, A. E., Kyriakopoulou, D., and Malathrakis, N. E. 2003. In vitro and in vivo activity of cyprodinil and pyrimethanil on $\mathrm{Bo}$ trytis cinerea isolates resistant to other botryticides and selection for resistance to pyrimethanil in a greenhouse population in
Greece. Eur. J. Plant Pathol. 109:173-182.

29. Pillonel, C., and Meyer, T. 1997. Effect of phenylpyrroles on glycerol accumulation and protein kinase activity of Neurospora crassa. Pestic. Sci. 49:229-236.

30. Raposo, R., Delcan, J., Gomez, V., and Melgarejo, P. 1996. Distribution and fitness of isolates of Botrytis cinerea with multiple fungicide resistance in Spanish greenhouses. Plant Pathol. 45:497-505.

31. Raposo, R., Gomez, V., Urrutia, T., and Melgarejo, P. 2000. Fitness of Botrytis cinerea associated with dicarboximide resistance. Phytopathology 90:1246-1249.

32. Rosslenbroich, H. J., and Stuebler, D. 2000. Botrytis cinerea - History of chemical control and novel fungicides for its management. Crop Prot. 19:557-561.

33. Tuite, J. 1969. Plant Pathological Methods Burgess Publishing Company, Minneapolis, MN

34. Vermeulen, T., Schoonbeek, H., and De Waard M. A. 2001. The ABC transporter BcatrB from Botrytis cinerea is a determinant of the activity of the phenylpyrrole fungicide fludioxonil. Pest Manag. Sci. 57:393-402.

35. Vignutelli, A., Hilber-Bodmer, M., and Hilber, U. W. 2002. Genetic analysis of resistance to the phenylpyrrole fludioxonil and the dicarboximide vinclozoline in Botryotinia fuckeliana (Botrytis cinerea). Mycol. Res. 106:329335.

36. Yourman, L. F., and Jeffers, S. N. 1999. Resistance to benzimidazole and dicarboximide fungicides in greenhouse isolates of Botrytis cinerea. Plant Dis. 83:569-575.

37. Yourman, L. F., Jeffers, S. N., and Dean, R. A. 2000. Genetic analysis of isolates of Botrytis cinerea sensitive and resistant to benzimidazole and dicarboximide fungicides. Phytopathology 90:851-859.

38. Ziogas, B. N., and Kalamarakis, A. E. 2001 Phenylpyrrole fungicides: Mitotic instability in Aspergillus nidulans and resistance in Botrytis cinerea. J. Phytopathol. 149:301-308.

39. Ziogas, B. N., Markoglou, A. N., and Malandrakis, A. A. 2003. Studies on the inherent resistance risk to fenhexamid in Botrytis cinerea. Eur. J. Plant Pathol. 109:311-317.

40. Ziogas, B. N., Markoglou, A. N., and Spyropoulou, V. 2005. Effect of phenylpyrroleresistance mutations on the ecological fitness of Botrytis cinerea and their genetical basis in Ustilago maydis. Eur. J. Plant Pathol. 113:83100. 